\title{
Synthesis and Electrochemical Study of the Ir(III) Complexes Containing the Diphenyl-quinoline, -Quinoxaline and Pyrazolonate Ligands
}

\author{
Hyun-Shin Lee and Yunkyoung $\mathrm{Ha}^{*}$ \\ Department of Information Display Engineering, Hongik University, Seoul 121-791, Korea. ${ }^{*}$ E-mail: ykha@hongik.ac.kr \\ Received September 3, 2010, Accepted December 6, 2010
}

\begin{abstract}
$\operatorname{Ir}(\mathrm{dpq} / \mathrm{dpqx})_{2}(\mathrm{przl}-\mathrm{R})$ complexes were prepared and their electrochemical properties were investigated, where dpq, dpqx and przl-R represent 2,3-diphenylquinoline, 2,3-diphenylquinoxaline and $N$-phenyl-R-pyrazolonate derivatives, respectively. The iridium complexes containing dpq and dpqx as main ligands were reported to show red phosphorescence, and involvement of a pyrazolonate ancillary ligand in the iridium complexes led to high luminous efficiency for organic light-emitting diodes. In this study, we synthesized red phosphorescent iridium complexes containing a new pyrazolonate ancillary ligand and investigated the HOMOs, LUMOs and resulting electrochemical gaps of $\operatorname{Ir}(\mathrm{dpq} / \mathrm{dpqx})_{2}$ (przl-R) by cyclic voltammetry. The emission wavelengths of the complexes at $600-640 \mathrm{~nm}$ were consistent with the gaps of $1.95-2.03 \mathrm{eV}$ measured from reduction and oxidation potentials of the complexes.
\end{abstract}

Key Words : Iridium complex, Pyrazolonate (prz-R), dpq/dpqx ligands, Red phosphorescence, Electrochemical properties

\section{Introduction}

The iridium complexes have been utilized in practical applications such as organic light-emitting diodes (OLEDs) and lightemitting electrochemical cells (LECs). Since the iridium metal center can have the large d-orbital splitting relative to the other transition metals, it is rather easy to tune the emission color of its complexes by modification of the ligands in the Ir sphere. ${ }^{1-2}$ The lowest excited state is determined by the admixture of the MLCT and LC transitions, which is associated to the main ligands and ancillary ligand of the complexes. For the tuning of the emission color, there are some strategies involving the substituent effect or the control of the $\pi$ conjugation length. However, the relatively long phosphorescence life-time of the iridium complexes could cause the triplet-triplet (T-T) annihilation at high currents, and thus it might lower the efficiency in the application of the OLEDs. ${ }^{3-5}$

As recently reported, introduction of a new bulky ancillary ligand, pyrazolonate (przl), to red-emitting Eu and Ir complexes could not only improve the luminous efficiency but also lead to the saturated red emission. ${ }^{6-7}$ Previously, we also applied this concept to the iridium complexes of dpq/dpqx main ligands and reported luminous efficiency improvement of the complexes involving the pyrazolone-based ancillary ligands, 4-R-5-methyl2-phenyl-2,4-dihydro-pyrazol-3-one (przl-R) where dpq, dpqx and przl-R represent 2,3-diphenylquinoline, 2,3-diphenylquinoxaline and N-phenyl-4-R-pyrazolonate derivatives, respectively. ${ }^{8}$ Herein, we prepared the new iridium complexes of dpq/dpqx and przl-R ligands, and studied their electrochemical properties of these complexes with cyclic voltammetric method.

\section{Experimental Section}

Synthesis and Characterization. All reagents were purchased from Aldrich Co., except iridium trichloride hydrate $\left(\mathrm{IrCl}_{3}\right.$. $\mathrm{H}_{2} \mathrm{O}$ ), which was purchased from Strem Co. and used without further purification. All reactions were carried out under a nitrogen or argon atmosphere. Solvents were dried by standard procedures. All column chromatography was performed with the use of silica gel (230-mesh, Merck Co). Mass spectra were determined on JEOL, JMS-AX505WA, HP 5890 Series II Hewlett-Packard 5890A (capillary column) and ${ }^{1} \mathrm{H}$ NMR and ${ }^{13} \mathrm{C}$ spectra were recorded at ambient temperature on a Bruker 300 NMR spectrometer using standard parameters.

\footnotetext{
Synthesis of Ligands $(\mathrm{L}=$ przl series, 2,3-dpqx-F $, 4-\mathrm{Me}-2,3-$ dpq):
}

Prazolone Ligands (przl-R) - The new ancillary ligands, przl-R, were prepared according to the analogous procedure previously reported. ${ }^{8}$

4-Me-2,3-dpq and 2,3-dpqx-F - dpq and dpqx ligand derivatives were obtained according to Friedlander Reaction with the corresponding precursors, [2-aminoacetophenone (10.0 $\mathrm{mmol})$ and 2-phenyl-acetophenone $(10.0 \mathrm{mmol})]$, and [1,2diaminobenzene $(10.0 \mathrm{mmol})$ and 4,4'-difluorobenzil $(10.0$ mmol)], respectively. ${ }^{9}$

Synthesis of Complexes: $\operatorname{Ir}(4-M e-2,3-d p q)_{2}($ przl-R), $\operatorname{Ir}((2,3-$ dpqx-F $)_{2}$ (przl-R):

$\operatorname{Ir}(4-M e-2,3-d p q)_{2}$ (przl-R) - The cyclometalated $\operatorname{Ir}($ III) $\mu-$ chloro-bridged dimer, (4-Me-2,3-dpq $)_{2} \operatorname{Ir}(\mu \mathrm{Cl})_{2} \operatorname{Ir}(4-\mathrm{Me}-2,3-$ $\mathrm{dpq})_{2}(1.9 \mathrm{mmol})$, was first prepared according to the Nonoyama method. ${ }^{10}$ In the second step, the resulting dimer and pyrazolonebased ligands $(6.5 \mathrm{mmol})$ were mixed with $\mathrm{Na}_{2} \mathrm{CO}_{3}(500 \mathrm{mg})$ in 2-ethoxyethanol $(30 \mathrm{~mL})$. The mixture was refluxed for $2 \mathrm{~h}$ and the red solid was filtered after cooling. $\operatorname{Ir}(4-\mathrm{Me}-2,3-\mathrm{dpq})_{2}$ (przl-R) were purified by chromatography on silica gel column with dichloromethane and recrystallization.

$\operatorname{Ir}\left(\left(\mathbf{2}, \mathbf{3}-\mathbf{d p q} \mathbf{x}-\mathbf{F}_{2}\right)_{\mathbf{2}}(\mathbf{p r z l}-\mathbf{R})\right.$ - The complexes were prepared from the reaction of 2,3-dpqxF , with $\mathrm{IrCl}_{3} \cdot \mathrm{H}_{2} \mathrm{O}$ and then treated with the pyrazolone-based ligands, similar to the procedure described above. $\operatorname{Ir}\left(2,3-\mathrm{dpqx}-\mathrm{F}_{2}\right)_{2}($ przl-R) were obtained as a bright red powder. 
The characterization results of the new iridium complexes are as follows:

Ir(4-Me-2,3-dpq) 2 (przl- $\left.\mathbf{C}_{6} \mathbf{H}_{4}-\mathbf{F}\right)$ - A red powder (Yield: 70\%). MS (FAB): $m / z 1077\left(\mathrm{M}^{+}\right) .{ }^{1} \mathrm{H} \mathrm{NMR}\left(\mathrm{CDCl}_{3}, 300 \mathrm{MHz}\right) \delta 8.47-$ 6.40 (aromatic H's 35H); $1.24\left(\mathrm{CH}_{3}\right.$ 's of przl, 3H each); 2.52 , 2.50 ( $\mathrm{CH}_{3}$ 's of 4-Me, $3 \mathrm{H}$ each). ${ }^{13} \mathrm{C}$ NMR (DMSO- $d_{6}, 125.8$ $\mathrm{MHz}) \delta 187.0,167.7\left(\mathrm{~d}, J_{\mathrm{CF}}=8.8\right), 162.3,161.9,149.3,148.4$, $148.1,147.9,147.3,146.6,146.3,144.9\left(\mathrm{~d}, J_{\mathrm{CF}}=6.3\right), 138.6$, $138.4,136.5\left(\mathrm{~d}, J_{\mathrm{CF}}=6.3\right), 136.4\left(\mathrm{~d}, J_{\mathrm{CF}}=2.5\right), 132.4,130.3$, $129.5,129.4,129.3,129.0,128.9,128.8\left(\mathrm{~d}, J_{\mathrm{CF}}=6.3\right), 128.3$, $127.2,126.6,126.4,125.5,125.1,124.8,120.1\left(\mathrm{~d}, J_{\mathrm{CF}}=2.5\right)$, 118.9, 115.2 (aromatic C's); 104.8 (CH's); 16.3, 16.2, 16.1 $\left(\mathrm{CH}_{3}\right.$ 's $)$.

Ir(4-Me-2,3-dpq $)_{2}\left(\right.$ przl- $\left.\mathbf{C}_{6} \mathrm{H}_{4}-\mathrm{N}\left(\mathrm{CH}_{3}\right)_{2}\right)$ - A red powder (Yield: 65\%). MS (FAB): $m / z 1101\left(\mathrm{M}^{+}\right) .{ }^{1} \mathrm{H}$ NMR $\left(\mathrm{CDCl}_{3}\right.$, $300 \mathrm{MHz}$ ) $\delta$ 8.56-6.39 (aromatic H's 35H); 1.39, 1.27, 1.19 ( $\mathrm{CH}_{3}$ 's of przl, 3H each); 2.47, 2.46 ( $\mathrm{CH}_{3}$ 's of 4-Me, 3H each). ${ }^{13} \mathrm{C}$ NMR (DMSO- $\left.d_{6}, 125.8 \mathrm{MHz}\right) \delta 188.4,167.8,167.7,163.3$, 152.0, 150.0, 148.7, 148.0, 146.9, 146.8, 146.4, 144.6, 144.5, 138.6, 138.9, 138.6, 138.5, 136.5, 132.4, 132.3, 130.4, 129.8, $129.5,129.4,129.3,128.9,128.8,128.7,128.2,127.1,127.0$, $126.9,126.6,126.3,125.4,124.8,124.7,124.3,120.0,119.9$, 119.0, 110.5 (aromatic C's); 104.6 (CH's); $40.0\left(\mathrm{~N}\left(\mathrm{CH}_{3}\right)_{2}\right.$ 's), $16.2,16.1\left(\mathrm{CH}_{3}\right.$ 's $)$.

Ir(4-Me-2,3-dpq) 2 (przl- $\left.\mathbf{C}_{6} \mathbf{H}_{\mathbf{4}}-\mathbf{C}_{\mathbf{1 0}} \mathbf{H}_{7}\right)$ - A red powder (Yield: 68\%). MS (FAB): $m / z 1108\left(\mathrm{M}^{+}\right) .{ }^{1} \mathrm{H} \mathrm{NMR}\left(\mathrm{CDCl}_{3}, 300 \mathrm{MHz}\right)$ $\delta$ 8.50-6.39 (aromatic H's 38H); $1.19\left(\mathrm{CH}_{3}\right.$ 's of przl, 3H each); 2.50, 2.52 ( $\mathrm{CH}_{3}$ 's of 4-Me, 3H each). ${ }^{13} \mathrm{C}$ NMR (DMSO- $d_{6}$, $125.8 \mathrm{MHz}) \delta 188.2,167.6,162.3,149.4,148.5,148.2,148.0$, $147.4,146.7,146.4,144.9,144.5,138.6,138.3,136.7,133.4$, $132.5,131.8,130.5,130.3,129.8,129.5,129.2,129.1,128.7$, $128.3,128.0,127.7,127.3,127.0,126.8,126.7,126.0,125.7$, 125.5, 125.2, 124.9, 124.7, 123.7, 120.1, 119.0 (aromatic C's); 105.0 (CH's); 16.3, $16.2\left(\mathrm{CH}_{3}\right.$ 's).

$\operatorname{Ir}\left(\mathbf{2 , 3 - d p q x}-\mathbf{F}_{2}\right)_{\mathbf{2}}\left(\mathbf{p r z l}-\mathbf{C}_{\mathbf{6}} \mathbf{H}_{\mathbf{4}}-\mathbf{F}\right)-\mathrm{A}$ red powder (Yield: $\left.73 \%\right)$. MS (FAB): $m / z$ 1122( $\left.\mathrm{M}^{+}\right) .{ }^{1} \mathrm{H} \mathrm{NMR}\left(\mathrm{CDCl}_{3}, 300 \mathrm{MHz}\right) \delta 8.33-$ 6.17 (aromatic H's $31 \mathrm{H}) ; 1.25\left(\mathrm{CH}_{3}\right.$ 's of przl, $3 \mathrm{H}$ each). ${ }^{13} \mathrm{C}$ NMR (DMSO- $\left.d_{6}, 125.8 \mathrm{MHz}\right) \delta 188.2,168.0\left(\mathrm{~d}, J_{\mathrm{CF}}=8.8\right)$, $163.0,162.6,152.3,150.7,150.3,148.8,148.2,147.2,146.9$, $145.7\left(\mathrm{~d}, J_{\mathrm{CF}}=6.3\right), 139.6,139.4,137.9\left(\mathrm{~d}, J_{\mathrm{CF}}=6.3\right), 137.3$ $\left(\mathrm{d}, J_{\mathrm{CF}}=2.5\right), 131.3,130.4,130.1,129.9,129.7,129.5\left(\mathrm{~d}, J_{\mathrm{CF}}=\right.$ 6.3), 129.2, 128.3, 127.5, 127.6, 126.5, 126.0, 125.6, 121.3(d, $\left.J_{\mathrm{CF}}=2.5\right), 120.1,117.9$ (aromatic C's), 105.0 (CH's).

Ir(2,3-dpqx- $\left.\mathbf{F}_{2}\right)_{\mathbf{2}}\left(\mathbf{p r z l}-\mathbf{C}_{\mathbf{6}} \mathbf{H}_{\mathbf{4}}-\mathbf{C}_{\mathbf{1 0}} \mathbf{H}_{7}\right)-\mathrm{A}$ red powder (Yield: 75\%). MS (FAB): $m / z 1154\left(\mathrm{M}^{+}\right) .{ }^{1} \mathrm{H} \mathrm{NMR}\left(\mathrm{CDCl}_{3}, 300 \mathrm{MHz}\right)$ $\delta 8.37-6.16$ (aromatic H's $34 \mathrm{H}) ; 1.25$ and $1.23\left(\mathrm{CH}_{3}\right.$ 's of przl, $3 \mathrm{H}$ each). ${ }^{13} \mathrm{C}$ NMR (DMSO- $\left.d_{6}, 125.8 \mathrm{MHz}\right) \delta 189.6,168.9$, 164.0, 150.9, 150.3, 149.9, 149.7, 149.1, 147.9, 147.7, 146.5, $146.1,140.8,140.5,138.5,135.2,134.3,133.8,132.2,132.0$, $131.1,130.8,130.6,130.5,130.1,129.9,129.6,129.0,128.8$, $128.6,128.2$, 128.0, 127.7, 127.0, 126.9, 126.5, 126.2, 126.0, 125.3, 122.1, 120.8 (aromatic C's); 106.2 (CH's).

Optical Measurements. UV-vis absorption spectra were measured on a Hewlett Packard 8425A spectrometer. PL spectra were measured on a Perkin Elmer LS 50B spectrometer. UV-vis and PL spectra of the iridium complexes were measured in a $10^{-5} \mathrm{M}$ dilute $\mathrm{CH}_{2} \mathrm{Cl}_{2}$ solution and in the PMMA film. The PMMA film was fabricated by the spin-coating onto the glass substrate with $10 \mathrm{wt} \%$ Ir complexes of PMMA in 1,2-dichloroethane solution and the following solvent evaporation.

\section{Results and Discussion}

We previously reported that the $\operatorname{Ir}(\mathrm{III})$ complexes containing the przl-based ancillary ligands exhibited the higher luminescent efficiency compared to the acac-based complexes. ${ }^{8}$ It is consistent with the premise that przl ligands in the complexes have not only suitable triplet energy levels matching $5 \mathrm{~d}$ orbital of the iridium center, but also provide good carrier transporting properties. The energy level matching may lead to better metalto-ligand charge transfer (MLCT), resulting in high luminous efficiency of the complex and improvement of carrier transport can lead to better performance of the device. Herein we prepared new przl ligands, 4-R-5-methyl-2-phenyl-2,4-dihydropyrazol-3-one $(\mathrm{R}=p$-fluorophenyl, $p$-dimethylaminophenyl, $p$-naphthyl) and their iridium complexes as shown in Fig. 1. The R groups were chosen to investigate the substituent effects in the przl-based ligands with respect to the luminescence properties of their complexes. The main ligand (L), 2,3dpqx- $\mathrm{F}_{2}$ and 4-Me-2,3-dpq, were synthesized according to the procedure reported previously.

The UV-vis absorption spectra of the complexes in $\mathrm{CH}_{2} \mathrm{Cl}_{2}$ are shown in Fig. 2(a). The absorption patterns of these complexes are similar. The strong absorption bands between 200 and $400 \mathrm{~nm}$ in the ultraviolet region are assigned to the spin allowed ${ }^{1} \pi-\pi^{*}$ transition of the cyclometallated 4-Me-2,3-dpq or 2,3-dpqx- $\mathrm{F}_{2}$ ligands in the complexes. The weak bands between
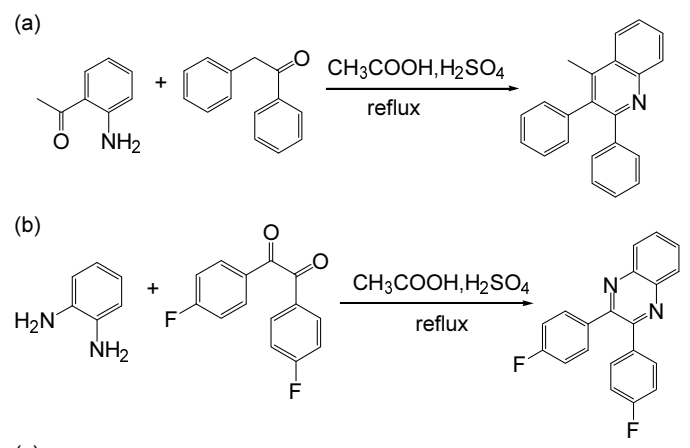

(c)
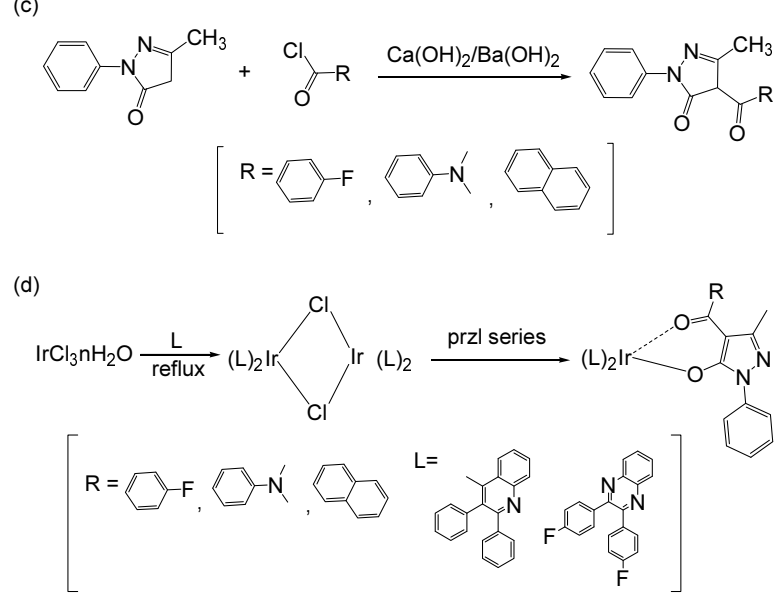

Figure 1. (a) Synthetic scheme of the ligands, 4-Me-2,3-dpq (b) 2,3dpqx- $F_{2}$ (c) przl-based ligands (d) Ir complexes. 
(a)

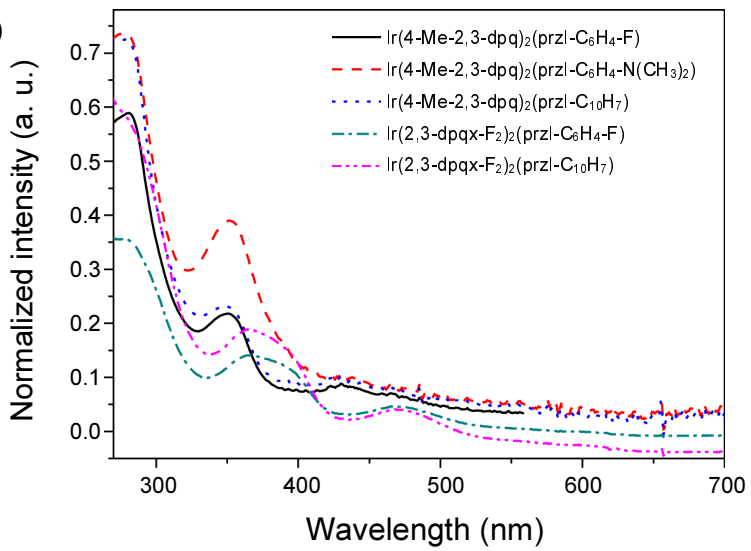

(c)

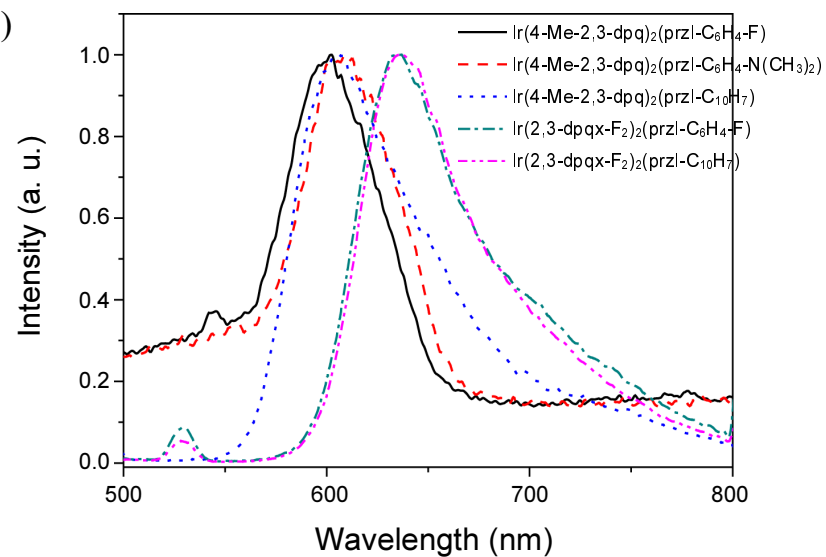

(b)

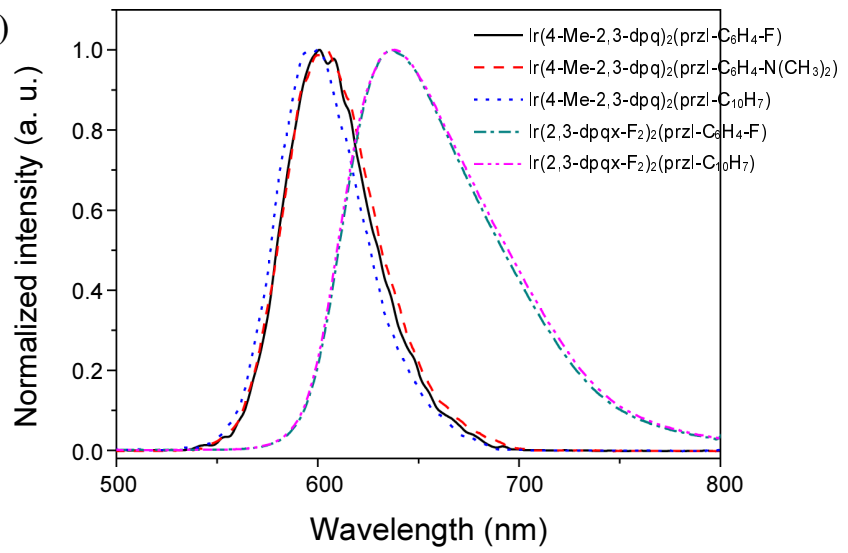

(d)

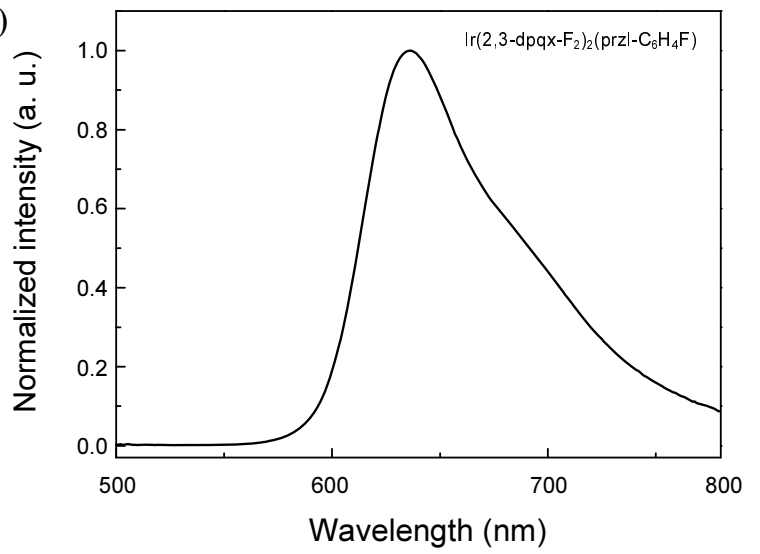

Figure 2. (a) UV-vis spectra of Ir complexes (b) solution PL spectra in the $10^{-5} \mathrm{M} \mathrm{CH}_{2} \mathrm{Cl}_{2}$ of Ir complexes (c) solid PL spectra of the complexes doped (10 wt \%) in PMMA films (d) EL spectra of the device with $\operatorname{Ir}\left(2,3-\mathrm{dpqx}-\mathrm{F}_{2}\right)_{2}\left(\right.$ przl- $\left.\mathrm{C}_{6} \mathrm{H}_{4} \mathrm{~F}\right)$.

400 and $500 \mathrm{~nm}$ in the visible region can be assigned to the spin-allowed metal-to-ligand charge transfer band ( ${ }^{1}$ MLCT). The weaker absorption band at the longer wavelength can be attributed to the spin-forbidden ${ }^{3}$ MLCT and ${ }^{3} \pi-\pi^{*}$ transition enhanced by the spin-orbit coupling. The formally spin forbidden ${ }^{3}$ MLCT gains the intensity by mixing with the higher-lying ${ }^{1}$ MLCT through the strong spin-orbit coupling on the Ir center.

The photoluminescence (PL) spectra of the Ir complexes in $\mathrm{CH}_{2} \mathrm{Cl}_{2}$ solution are shown in Fig. 2(b). The emission maxima for $\operatorname{Ir}(4-\mathrm{Me}-2,3-\mathrm{dpq})_{2}($ przl-R) appeared around $600 \mathrm{~nm}$, and those of $\operatorname{Ir}\left(2,3-\mathrm{dpqx}-\mathrm{F}_{2}\right)_{2}$ (przl-R) were shown around $640 \mathrm{~nm}$, regardless of the different R-substituents. The PL peak wavelengths were not affected by the substituent difference in the ancillary ligand. Thus, the main ligands, dpq and dpqx derivatives, are major moieties that determine the emission color of their complexes. This is also supported by the previously reported PL data of their corresponding complexes, $\operatorname{Ir}(4-\mathrm{Me}-2,3-\mathrm{dpq})_{2}$ (acac) and $\operatorname{Ir}\left(2,3-d p q x-F_{2}\right)_{2}(\mathrm{acac})$, which showed the peaks at 604 and $631 \mathrm{~nm}$, respectively. ${ }^{8}$ Meanwhile, the R groups in the ancillary ligands have an insignificant effect on the emission color determination of the complexes.

The solid structures of the new complexes prepared in this study were presumed to have geometric isomers as the X-ray structure of $\operatorname{Ir}(4-\mathrm{Me}-2,3-\mathrm{dpq})_{2}\left(\right.$ przl- $\left.\mathrm{C}_{6} \mathrm{H}_{4} \mathrm{Cl}\right)$ previously reported. ${ }^{11}$ The complexes were not sublimable enough to be fabricated in the electroluminescence (EL) device. We attribute such low sublimability to the heavy molecular weight (more than
$1000 \mathrm{~g} / \mathrm{mol}$ ) of the complexes. Thus, their luminescence properties in the solid films were investigated for the possible application to polymer-based fabrication of the EL devices, instead. The PL spectra of Ir(4-Me-2,3-dpq) 2 (przl-R) doped (10 wt \%) in the poly-(methylmethacrylate) (PMMA films) exhibited the emission between 606 and $610 \mathrm{~nm}$, as shown in Fig. 2(c). These solid PLs showed a small bathochromic shift and broader emission than the solution PLs of the complexes. Such red-shift and larger full width of half maximum (FWHM) of the film PL spectra were attributed to the formation of complex excimers through the strong $\pi-\pi$ interaction. ${ }^{12,13}$ The iridium complexes of 4-Me-2,3-dpq and przl-R also showed similar phenomena.

We investigated electrochemical properties of the Ir complexes by the cyclic voltammetry (CV), which reveal their positions of the HOMO/LUMO. ${ }^{14,15}$ The oxidation potentials which indicates the HOMOs of $\operatorname{Ir}(4-\mathrm{Me}-2,3-\mathrm{dpq})_{2}$ (przl-R) were reversible in the range of $0.32-0.39 \mathrm{eV}$ relative to an internal ferrocenium/ferrocene reference $\left(\mathrm{Fc}^{+} / \mathrm{Fc}\right)$. The deduced HOMO levels of the $\operatorname{Ir}(4-\mathrm{Me}-2,3-\mathrm{dpq})_{2}\left(\right.$ przl- $\left.\mathrm{C}_{6} \mathrm{H}_{4} \mathrm{~F}\right)$ and $\operatorname{Ir}(4-\mathrm{Me}-2,3-$ dpq $)_{2}\left(\right.$ przl- $\left.\mathrm{C}_{6} \mathrm{H}_{4}-\mathrm{C}_{10} \mathrm{H}_{7}\right)$ were lowest $(-5.19$ and $-5.18 \mathrm{eV}$, respectively), while that of $\operatorname{Ir}(4-\mathrm{Me}-2,3-\mathrm{dpq})_{2}\left(\right.$ przl- $\left.\mathrm{C}_{6} \mathrm{H}_{4}-\mathrm{N}\left(\mathrm{CH}_{3}\right)_{2}\right)$ was highest with $-5.12 \mathrm{eV}$. Therefore, it is possible to consider that an electron donating and an electron withdrawing group in przl-R effectively raises and lowers the HOMO level of the complex, respectively. In addition, increase of the $\pi$ conjugation length in przl-R contributes to lowering of HOMO level of the complex. The oxidation potentials of the iridium complexes 
Table 1. Physical parameters for the complexes

\begin{tabular}{|c|c|c|c|c|c|c|c|}
\hline Ir complex & $\lambda_{\mathrm{abs}} / \mathrm{nm}^{a}$ & $\lambda_{\mathrm{em}} / \mathrm{nm}^{a}$ & $E_{\mathrm{ox}} / \mathrm{V}^{b}$ & $E_{\text {red }} / \mathrm{V}^{b}$ & $\mathrm{HOMO} / \mathrm{eV}^{c}$ & $\mathrm{LUMO} / \mathrm{eV}^{c}$ & $\Delta E / \mathrm{eV}^{d}$ \\
\hline $\operatorname{Ir}(4-\mathrm{Me}-2,3-\mathrm{dpq})_{2}\left(\right.$ przl- $\left.\mathrm{C}_{6} \mathrm{H}_{4}-\mathrm{F}\right)$ & 350,430 & 600 & 0.39 & -1.64 & -5.19 & -3.16 & 2.03 \\
\hline $\operatorname{Ir}(4-\mathrm{Me}-2,3-\mathrm{dpq})_{2}\left(\right.$ przl- $\left.\mathrm{C}_{6} \mathrm{H}_{4}-\mathrm{N}\left(\mathrm{CH}_{3}\right)_{2}\right)$ & 352,430 & 601 & 0.32 & -1.67 & -5.12 & -3.13 & 2.0 \\
\hline $\operatorname{Ir}(4-\mathrm{Me}-2,3-\mathrm{dpq})_{2}\left(\right.$ przl- $\left.\mathrm{C}_{10} \mathrm{H}_{7}\right)$ & 348,430 & 600 & 0.38 & -1.64 & -5.18 & -3.16 & 2.02 \\
\hline $\operatorname{Ir}\left(2,3-\text { dpqx}-\mathrm{F}_{2}\right)_{2}\left(\right.$ przl- $\left.\mathrm{C}_{6} \mathrm{H}_{4}-\mathrm{F}\right)$ & 366,468 & 637 & $0.23^{e}$ & -1.72 & $-5.03^{e}$ & -3.08 & $1.95^{e}$ \\
\hline $\operatorname{Ir}\left(2,3-\text { dpqx }-\mathrm{F}_{2}\right)_{2}\left(\right.$ przl- $\left.\mathrm{C}_{10} \mathrm{H}_{7}\right)$ & 365,468 & 637 & $0.22^{e}$ & -1.72 & $-5.02^{e}$ & -3.08 & $1.95^{e}$ \\
\hline
\end{tabular}

${ }^{a}$ Measured in $\mathrm{CH}_{2} \mathrm{Cl}_{2}$ solution. ${ }^{b}$ scan rate: $100 \mathrm{mV} / \mathrm{s}$, Electrolyte: tetrabutylammonium hexafluorophosphate. The potentials are quoted against the internal ferrocene standard. ${ }^{c}$ Deduced from the equation $\mathrm{HOMO}=-4.8-E_{o x}, \mathrm{LUMO}=-4.8-E_{\text {red }}{ }^{d, e}$ Calculated from the optical edge and the relation $\Delta E=$ HOMO - LUMO.

Table 2. Characteristic of OLED devices with the iridium complex

\begin{tabular}{cccccc}
\hline Ir complexes & $\begin{array}{c}\text { PL } \lambda_{\max } \\
(\mathrm{nm})\end{array}$ & $\begin{array}{c}\text { EL } \lambda_{\max } \\
(\mathrm{nm})\end{array}$ & $\begin{array}{c}\text { Luminance }^{a} \\
\left(\mathrm{~cd} / \mathrm{m}^{2}\right)\end{array}$ & $\begin{array}{c}\text { Luminance Efficiency }^{b} \\
(\mathrm{~cd} / \mathrm{A})\end{array}$ & $\begin{array}{c}\text { CIE } \\
\text { Coordinates }\end{array}$ \\
\hline $\operatorname{Ir}\left(2,3-\mathrm{dpqx}-\mathrm{F}_{2}\right)_{2}\left(\right.$ przl- $\left.\mathrm{C}_{6} \mathrm{H}_{4} \mathrm{~F}\right)$ & 637 & 636 & 1212 & 2.61 & $(0.689,0.309)$ \\
\hline$a, b$ Luminance and luminance efficiency were measured at 11 and $5 \mathrm{~V}$, respectively. & & &
\end{tabular}

containing 2,3-dpqx- $\mathrm{F}_{2}$ were not clearly shown in the electrochemical windows and thus their HOMOs were estimated from their optical edges. In the meantime, the reduction potentials of the complexes did not show the reversible wave. The reduction potentials of the complexes in this study were measured between -1.64 and $-1.72 \mathrm{eV}$. The electronic effects by the electron donating/withdrawing groups on the LUMOs of the complexes were also consistent with their HOMO results. However, it was found that the resulting $\Delta \mathrm{Es}\left(\mathrm{E}_{\mathrm{ox}}-\mathrm{E}_{\text {red }}\right)$ of the complexes were almost identical in the range of $2.0-2.03 \mathrm{eV}$ for $\operatorname{Ir}(4-\mathrm{Me}-2,3-\mathrm{dpq})_{2}$ (przl-R) and 3.07 - $3.08 \mathrm{eV}$ for $\operatorname{Ir}\left(2,3-\mathrm{dpqx}-\mathrm{F}_{2}\right)$ (przl-R). Thus, the emission color which is determined by the HOMO and LUMO gap of the complexes did not show a substantial change related to the substituent in the ancillary ligands. The detailed CV data were summarized in Table 1. Therefore, the substituents on przl ancillary ligand studied herein did not have a significant effect on PL color determination of their iridium complexes though electronic properties of ancillary substituents had an influence on the HOMOs and LUMOs of the complexes individually. On the other hand, our study confirmed that the emission color of the iridium complexes were mostly determined by the main ligand, dpq/dpqx, in the complexes.

The electroluminescence (EL) properties were also investigated. The configuration of the EL devices with $\operatorname{Ir}\left(2,3-\mathrm{dpqx}-\mathrm{F}_{2}\right)_{2}$ (przl- $\left.\mathrm{C}_{6} \mathrm{H}_{4}-\mathrm{F}\right)$ was ITO/ NPB $(50 \mathrm{~nm}) / \mathrm{CBP}: 8 \%$ Dopant $(30 \mathrm{~nm}) /$ Bphen $(30 \mathrm{~nm}) / \mathrm{Liq}(2 \mathrm{~nm}) / \mathrm{Al}(100 \mathrm{~nm})$. As shown in Fig. 3(d), the EL spectrum resembles its corresponding PL spectrum from the dilute solution, indicating that the same optical transition is responsible for the light emission. The luminance and luminous efficiency of $\operatorname{Ir}\left(2,3-\mathrm{dpqx}-\mathrm{F}_{2}\right)_{2}\left(\text { przl- } \mathrm{C}_{6} \mathrm{H}_{4}-\mathrm{F}\right)_{2}$ were $1212 \mathrm{~cd} / \mathrm{m}^{2}$ and $2.61 \mathrm{~cd} / \mathrm{A}$, respectively.

\section{Conclusion}

The new red phosphorescent iridium complexes, $\operatorname{Ir}(4-\mathrm{Me}-$ 2,3-dpq $)_{2}\left(\right.$ przl-R) and $\operatorname{Ir}\left(2,3-d p q x-F_{2}\right)_{2}($ przl-R), were prepared for the potential application to OLEDs, and their photoabsorption, PL and electrochemical properties were investigated. The main ligands, dpq and dpqx, had an important effect on the photophysical properties of their iridium complexes and the resulting emission color of the complexes. The electron-donating/withdrawing properties of the substituents in the przl ancillary ligands were also reflected in the energy levels of the HOMOs and the LUMOs of the complexes, respectively. However, the electrochemical gaps between their HOMO and LUMO levels remained almost the same and thus the emission color which was determined by these gaps was not affected significantly.

Acknowledgments. This work was supported by National Research Foundation of Korea Grant (2010-0017189).

\section{References}

1. Censo, D. D.; Fantacci, S.; Angelis, F. D.; Klein, C.; Evans, N.; Kalyanasundaram, K.; Bolink, H. J.; Gratzel, M.; Nazeeruddin, M. K. Inorg. Chem. 2008, 47, 980.

2. Li, J.; Djurovich, P. I.; Alleyne, B. D.; Yousufuddin, M.; Ho, N. N.; Thomas, J. C.; Peters, J. C.; Bau, R.; Thompson, M. E. Inorg. Chem. 2005, 44, 1713.

3. Baldo, M. A.; Thompson, M. E.; Forrest, S. R. Nature 2000, 403, 750.S.

4. Lamansky, S.; Djurovich, P.; Murphy, D.; Abdel-Razzaq, F.; Lee, H. E.; Adachi, C.; Burrow, P. E.; Forrest, S. R.; Thompson, M. E. J. Am. Chem. Soc. 2001, 123, 4304.

5. Lowry, M. S.; Bernhard, S. Chem. Eur. J. 2006, 12, 7970.

6. Shi, M.; Li, F.; Yi, T.; Zhang, D.; Hu, H.; Huang, C. Inorg. Chem. 2005, 44, 8929.

7. ZhaO, Q.; Jiang, C. Y.; Shi, M.; Li, F. Y.; Yi, T.; Cao, Y.; Huang, C. H. Organometallics 2006, 259, 3631.

8. Lee, H.; Seo, J.; Choi, M. K.; Kim, Y.; Ha, Y. Journal of Physics and Chemistry of Solids 2008, 69, 3697.

9. Riesgo, E. C.; Jin, X.; Thummel, R. P. J. Org. Chem. 1966, 61, 3017.

10. Nonoyama, M. J. Organomet. Chem. 1975, 86, 263.

11. Lee, H. S.; Ahn, S. Y.; Huh, H. S.; Ha, Y. J. Organomet. Chem. 2009, 694, 3325.

12. Lee, J.; Chu, H. Y.; Kim, S. H.; Do, L. M.; Zyung, T.; Hwang, D. H. Opt. Mater. 2002, 21, 205.

13. Gupta, D.; Katiyar, M.; Deepak, 0. Opt. Mater. 2006, 28, 295.

14. Thomas, K. R. J.; Velusamy, M.; Lin, J. T.; Chien, C.; Tao, Y.; Wen, Y. S.; Hu, Y.; Chou, P. Inorg. Chem. 2005, 44, 5677.

15. Zhao, Q.; Jiang, C.; Shi, M.; Li, F.; Yi, T.; Cao, Y.; Huang, C. Organnometallics 2006, 25, 3631. 